\section{A resistência}

\section{religiosa}

\section{afro-brasileira}

Resenha: SANT'ANNA SOBRINHO, José. Terreiros Egúngún: um culto ancestral afro-brasileiro. Salvador: EDUFBA, 2015. 284 p.

\section{José Marcos Brito Rodrigues}

Universidade Federal da Bahia (UFBA) jmbr@bol.com.b

Poucos autores se aventuraram nos estudos das africanidades para investigar o culto dos eguns (espíritos dos mortos), até o momento um tema de rara abordagem. Esse universo peculiar é revelado pelo professor José Sant'Anna Sobrinho, através do livro, fruto da sua pesquisa de mestrado em Educação e Contemporaneidade pela UNEB, publicado pela EDUFBA num momento de tantos conflitos, resistência e equívocos de informação a cerca das culturas na diáspora africana.

Para começo de conversa, vale salientar que se trata de um relato sobre a tradição iorubá, a última vertente africana entre as que se instalaram na Bahia, se mesclaram, transformaram-se ou desapareceram. Assim, de acordo com o título, o livro faz uma abordagem sobre o culto dos antepassados trazido da África, adaptado ao contexto da diáspora, ou seja, um legado da cultura africana onde hoje estão a Nigéria e o Golfo do Benin. É um trabalho de fôlego e consistência cuja leitura atrai pela contextualização do culto e pela discussão levantada, uma vez que vivemos um tempo marcado pelo pragmatismo da intolerância religiosa num país que se proclama na condição de um estado laico.

Odeere: revista do programa de pós-graduação em Relações Étnicas e Contemporâneidade - UESB. Ano 1, número 1, volume 1, Janeiro - Junho de 2016. 
A pesquisa foi construída a partir da observação mais do que participante de alguém que nasceu e viveu dentro da religiosidade de origem africana, possuidor de conhecimento e sabedoria suficientes para inserir na investigação científica e revelar de forma muito criteriosa essa face da resistência ancestral. Material de rara frequência nos debates acadêmicos, a publicação se destaca pelo aspecto da originalidade e pela autoridade discursiva do pesquisador ao longo do texto, cujo relato nos conduz pelos terreiros, suas origens, organização, expansão e transformação do culto Egúngún na Ilha de Itaparica e em Salvador. A experiência etnográfica de José Sobrinho torna rico o diálogo estabelecido com suas relações étnicas no cenário da contemporaneidade e com suas relações de alteridade, seja pela condição de pesquisador, seja de pertencente ao locus pesquisado.

Fora o valor acadêmico indiscutível, o livro parece abrir para o grande público o horizonte de um ambiente secreto com fronteiras bem estabelecidas e práticas reservadas. De forma muito didática e objetiva, o autor apresenta lugares e pessoas desconhecidas ou conhecidas por poucos, buscando aproximar e eliminar o estranhamento até mesmo de quem faz parte da comunidade religiosa. Com isso, transmite nas entrelinhas que o intuito é esclarecer sobre a descendência africana instalada na Bahia, adepta à ancestralidade masculina Egúngún, através de um trabalho narrativo dividido em cinco capítulos.

Ao ilustrar com exemplos da mitologia, o autor explica no primeiro capítulo o que vem a ser ancestralidade afro-brasileira mantida viva ao longo do tempo através de uma linguagem própria. Também apresenta antecedentes históricos do povo iorubá, a origem das manifestações religiosas africanas em território baiano, os terreiros Egúngún e sua simbologia representativa, os primeiros espaços, formas de organização e hierarquia. Seguindo a metodologia do seu interessante estudo, discute ainda o conceito de ancestralidade masculina e feminina, seus desdobramentos e a relação espiritual dos grupos familiares com a morte.

No capítulo seguinte, o pesquisador anuncia a expansão dos terreiros de culto egúngún entre 1980 e 2009, num panorama a partir de rupturas de lideranças, mudança e constituição de novas lideranças, as localizações dos espaços, calendários de cerimônias e entrevistas com pessoas importantes no culto. Também discorre sobre a vinculação de alguns orixás aos terreiros de ancestralidade masculina Egúngún.

Odeere: revista do programa de pós-graduação em Relações Étnicas e Contemporaneidade - UESB. Ano 1, número 1, volume 1, Janeiro - Junho de 2016. 
No bojo de suas observações, Sobrinho estima que a expansão dos terreiros Egúngún, a partir de 1980, deverá responder se a convivência entre os Orixás do panteão afro-brasileiro e os Egúngún, dentro da tradição, segue mantida em separado. Ao aprofundar sua argumentação, revela que desde a fundação original, o terreiro já tinha o hábito de reverenciar alguns Orixás pela relação já constituída com estas divindades, pela linguagem comum dentro dos cultos e a concessão de alguns títulos honoríficos.

O pesquisador expressa sua noção de pertencimento à diáspora e lembra que a criação dos terreiros foi resultado da resistência do povo de origem africana contra as elites brasileiras na época da escravidão, e também consequência da fragmentação do seu sistema familiar. Com isso, os africanos tiveram como estratégia reunir em um só lugar vários elementos simbólicos, ritos e celebrações de diferentes nações e grupos étnicos.

Em uma breve narrativa, o autor resume, no terceiro capítulo, a sua atuação como entrevistador no trabalho de campo, onde despreza o conceito de memória pelo fato do seu objeto estar na própria vivência particular, nos ritos práticos com a comunidade. Já que o culto é uma prática marcadamente realizada entre famílias, Sobrinho questiona sobre a atual condição de aprendizado da tradição ancestral Egúngún, seus rituais, princípio iniciático, o segredo e o mistério (awô), que, no passado, nunca fora revelado ao não iniciado, de fora da família, entre outros elementos.

O capítulo que segue traz um conjunto de dados levantados pela pesquisa de acordo com a metodologia aplicada, através de entrevistas e registro de anotações feitas na llha de Itaparica, Salvador e Lauro de Freitas. O autor mostra resultados que apontam aspectos (inclusive polêmicos) que podem gerar outras discussões dentro ou fora da academia e nas próprias comunidades de terreiro. Entre esses dados, chamam a atenção o crescente número de crianças presentes nas festas, homossexual não pode ser ojé e a alteração de liderança por tempo de iniciação.

O estudo apresenta novidades como o uso da tecnologia (máquinas fotográficas e filmadoras), algo antes impensado, nos espaços de culto. A questão da língua iorubá utilizada nas liturgias pelos Egúngún, e que a maioria das pessoas não domina, é um aspecto mencionado, mas não discutido no trabalho. Outro ponto polêmico levantado na pesquisa é que terreiros de orixá 
que cultuam Egúngún oriundos da ilha não têm aprovação das lideranças mais antigas, segundo a análise interpretativa do autor sobre a hierarquia nos terreiros.

No relato da pesquisa, certamente entre as respostas do trabalho de campo, aparecem a redução do preconceito aos terreiros graças à popularização dos mesmos e, com abertura aos visitantes, um novo conceito sobre os praticantes. Assim foi gerada a estratégia de resistência religiosa do afro-brasileiro através de alianças para sobreviver, cultuar suas crenças e suas entidades. A partir dos elementos apontados, o autor conclama todos os devotos a ter orgulho dos seus antepassados, assegurando a tradição para futuras gerações, apesar da invasão de alguns terreiros por segmentos evangélicos ou pela especulação imobiliária.

O último capítulo revela sua tentativa de contribuir para a valorização das religiões de origem africana e como consequência a redução do preconceito contra seus praticantes. Na luta contra a invisibilidade, o pesquisador assume a condição de um negro sujeito que fala de si e de sua cultura e busca reparar as falhas da história oficial hegemônica ensinada na escola.

A concepção de Sobrinho consiste na assertiva de que preservar essas tradições e seu legado é obrigação de todos, pois os terreiros e sacerdotes, os governos, outras religiões e formas de credo devem respeitar e entender que o outro é diferente. A proposta é seguir a palavra de ordem de combate à ocultação, à negação e à discriminação da cultura afro-brasileira. Por fim, a perspectiva é que novos caminhos sejam apontados na preservação dessa tradição ancestral.

Para quem acredita em destino, a vida tem dessas coisas. José Sant'Anna Sobrinho certamente estava num grande momento de sua vida intelectual quando fez o mestrado e um câncer na garganta o impediu de levar sua pesquisa aos debates depois de concluída. A natureza não the deu tempo de desfrutar o prazer de ver o seu trabalho publicado e a merecida repercussão. Ele se foi em 2011, mas aqui ficou o registro das lembranças expressas pela sua atuação. Enquanto isso, sua memória segue com quem o conheceu de perto e entre nós, que nunca nos preparamos o suficiente para perdas.

A publicação desse trabalho reforça a importância da pesquisa realizada e vem confirmar a existência de lacunas entre as faces das tradições afro-brasileiras no mundo das ciências humanas e sociais. Pela originalidade, já pode demarcar o seu espaço na lista entre os clássicos da antropologia.

Odeere: revista do programa de pós-graduação em Relações Étnicas e Contemporaneidade - UESB. Ano 1, número 1 , volume 1, Janeiro - Junho de 2016. 
José Marcos Brito Rodrigues: Mestre em Estudos Étnicos e Africanos e Bacharel em Comunicação (UFBA) com experiência profissional em emissoras de rádio e jornais. Autor de artigos e resenhas na imprensa, revistas científicas e anais de congressos e seminários, além do texto $O$ Lugar e a pesquisa, na coletânea Discutindo Etnicidades, de Jocélio Teles dos Santos (org.), EDUFBA, 2014. Email: jmbr@bol.com.br

Artigo recebido para publicação em: Março de 2016.

Artigo aprovado para publicação em: Abril de 2016.

Odeere: revista do programa de pós-graduação em Relações Étnicas e Contemporaneidade - UESB. Ano 1, número 1, volume 1, Janeiro - Junho de 2016. 